\title{
EKSISTENSI SD GMIT DI ROTE NDAO \\ (Studi Deskriptif Penempatan Guru PNS pada SD GMIT Rote Ndao-NTT)
}

\author{
Melki Manafe \\ Alumni Magister Manajemen Pendidikan FKIP Universitas Kristen Satya Wacana \\ Bambang Ismanto \\ Magister Manajamen Pendidikan FKIP Universitas Kristen Satya Wacana \\ bambang.ismanto@staff.uksw.edu
}

\begin{abstract}
ABSTRAK
Penelitian ini bertujuan untuk mendeskripsikan kerjasama Negara dan GMIT (melalui Yupenkris) dalam hal penempatan guru PNS yang diperbantukan pada SD GMIT yang ada di Kabupaten Rote Ndao.Penelitian ini juga menjelaskan bagaimana dinamika dan relasi tersebut serta dampaknya, secara deskriptif, pada eksistensi SD GMIT yang ada di Kabupaten Rote Ndao. Penelitian ini menggunakan metode Kualitatif Deskriptif dengan in-depth interview yang didukung oleh observasi, dokumentasi dan triangulasi.Data diperoleh dari 8 SD GMIT di Rote Ndao, dianalisis dengan model analisis Miles \& Huberman. Hasil penelitian menunjukkan bahwa penempatan guru PNS yang diperbantukan pada SD GMIT di Rote Ndao, secara mutlak, hanya diketahui oleh Negara (melalui Dinas Pendidikan). Hasil penelitian juga menemukan bahwa pada SD GMIT di Rote Ndao sama sekali tidak terdapat guru Yayasan. Bahkan lebih dari itu, baik dana pendidikan, tenaga pendidik maupun kependidikan adalah berasal dari Negara. Hasil-hasil inimenempatkan SD GMIT di Rote Ndao pada status quasistate school dimana SD GMIT adalah milik GMIT akan tetapi semua operasional (subsidi pendidikan dan sumber daya manusia/guru) selalu bergantung pada Negara.
\end{abstract}

Kata kunci: Negara, GMIT, Guru PNS yang diperbantukan, Eksistensi SD

\section{PENDAHULUAN}

Negara dan Gereja dalam hal subyeknya mempunyai kesamaan yakni warganegara (Sulasmono, 2010:17). Kesamaan dalam hal subjek, menurut Darmaputera (1994:16) menyebabkan ada bidang-bidang kehidupan yang selain diatur oleh Gereja juga diatur oleh Negara, salah satunya adalah di dalam bidang pendidikan.

Dalam uraian Pasal 9 Undang-Undang Sisdiknas memberikan gambaran deskriptif bagai-mana Negara melibatkan masyarakat dalam hal pendidikan seperti yang dijabarkan bahwa "masyarakat berkewajiban memberikan dukungan sumber daya dalam penyelenggaraan pendidikan". Hal ini dipertegas oleh
Cully (2009:3) yang membagi masyarakat berdasarkan keterlibatannya dalam kegiatan pendidikan ke dalam dua kategori yakni masyarakat Budaya (Negara) dan masyarakat Gereja.

Keterlibatan masyarakat Gereja dalam pendidikan dapat berlangsung dalam berbagai bentuk organisasi. Akan tetapi, bentuk organisasi yang lazim ialah berbentuk Yayasan Pendidikan Kristen yang biasanya didirikan oleh orang perorangan maupun oleh Sinode (Sulasmono, 2010:18)

Di Kabupaten Rote Ndao, Nusa Tenggara Timur (NTT), keterlibatan masyarakat Gereja dalam pendidikan ditunjukkan dengan pendirian Sekolah Swasta Kristen yang lebih dikenal dengan nama Sekolah GMIT yang berada di 
bawah naungan Sinode Gereja Masehi Injili di Timor (GMIT) melalui Yayasan Usaha Pendidikan Kristen (Yupenkris) dimana hingga saat ini terdapat sembilan belas (19) SD GMITdan satu (1) SMA Kristen (Mali, 2003 dalam Darmaningtyas, 2006: Laporan Tahunan Majelis Yupenkris GMIT, 2012).

Keberadaan SD GMIT yang ada di Rote Ndao menyebabkan terjalinnya kerjasama antara negara dan GMIT dalam hal pengelolaan persekolahan dengan adanya penempatan guru PNS yang diperbantukan pada SD GMIT yang ada di Rote Ndao. Kurniawan (2011), menjelaskan bahwa pentingnya kerjasama ini disebabkan guru merupakan salah satu komponen pendidikan yang sangat strategis dan banyak mengambil peran di dalam proses pendidikan secara luas khususnya dalam pendidikan persekolahan.

Hal ini dipertegas oleh Supriyoko (2011), bahwa penempatan guru PNS pada Sekolah Swasta, secara ideologi, merupakan wujud peng-hargaan Negara kepada pihak swasta atas perjuangannya dalam bidang pendidikan serta, secara teknis, bertujuan untuk pemerataan kualitas pendidikan.

Sirait \& Tri (2003:71) melaporkan bahwa, di satu sisi, penempatan guru PNS bermanfaat untuk kelangsungan sekolah swasta Kristen di NTT. Akan tetapi, bersamaan dengan itu pula, memunculkan kasus dimana Yayasan Pengelola kehilangan grip terhadap sekolahsekolah yang didirikannya. Di samping itu, tidak jarang pula muncul bargaining power oleh negara disebabkan oleh dominannya guru PNS yang diperbantukan pada sekolah swasta Kristen di NTT.

Oleh karena itu, penelitian ini bertujuan untuk mendeskripsikan bagaimana kerjasama, relasi dan dinamika antara negara dan GMIT dalam hal penempatan guru PNS yang diperbantukan pada SD GMIT di Rote Ndao. Lebih lanjut, penelitian ini juga bertujuan untuk menjabarkan dampak kerjasama dalam hal penempatan guru PNS yang diperbantukan, secara deskriptif, terhadap eksistensi SD GMIT di Rote Ndao.

\section{TINJAUAN PUSTAKA}

\section{Relasi Negara dan Gereja dalam Pendidikan di Indonesia}

Relasi antara Negara dan Gereja dalam pendidikan di Indonesia, dimulai ketika bangsa Portugis melakukan kegiatan perdagangan dan mendirikan sekolah seminari (Dirjen Bimas Kristen Protestan, 1982:4; Soemanto \& Soeyarno, 1983:35; Sirait \& Tri, 2003:23). Model persekolahan ini kemudian dilanjutkan oleh VOC dan Pemerintah Belanda ketika berkuasa di Indonesia (masa itu, Indonesia dikenal dengan nama Hindia Belanda) dengan diperbolehkannya zending (lembaga pekabaran Injil) mendirikan sekolah-sekolah swasta Kristen di Indonesia yang dominan banyak terletak di kawasan Indonesia Timur seperti di Pulau Ambon (1607) dan Pulau Timor (1710) (Suminto, 1986:4; Supriadi, 2005; Azra, 2008:125).

Dengan adanya Politik Etis yang diprakarsai oleh Van Deventer, sekolah swasta untuk mendidik kaum pribumi mulai didirikan di Jogjakarta, Kebumen, Purbalingga, Gombong (1913), Purworejo (1915), Magelang (1916), Purwakerto, Klaten, Sragen, Wates dan Surakarta (1921) (Wolterbeek, 1995:202 dalam Sulasmono, 2010:61)

Suminto (1986:4) menjabarkan bahwa realitas keberadaan sekolah swasta Kristen di Indonesia, tidak terlepas dari relasi antara Negara dan Gereja/zending dimana pendidikan digunakan sebagai misi pekabaran Injil dengan fungsi ganda dimana selain berfungsi sebagai kersteningpolitiek (politik kristenisasi) juga berfungsi untuk meminimalisir bahkan menghilangkan pemberontakan yang disebabkan oleh kaum Islam fanatik di Indonesia.

Saat Indonesia memproklamasikan kemerdekaannya, Pancasila khususnya di 
dalam sila "KeTuhanan Yang Maha Esa" menjadi dasar utama sekolah swasta Kristen di Indonesia tetap eksis. Sulasmono (2010:21) menjabarkan bahwa didalam sila KeTuhanan Yang Maha Esa mengandung arti bahwa:

a. Negara Indonesia bukan Negara Atheis

b. Negara Indonesia bukan Negara Agama

c. Di dalam Negara Indonesia terjalin relasi berbentuk pembedaan fungsi dalam semangat kerjasama antara Negara dan Agama.

Artian di atas, menjadi topangan Yayasan Pendidikan yang berorientasi Agama di Indonesia dalam mengelola sekolah swasta dengan ciri khas agama masing-masing sehingga sekolah-sekolah Swasta Kristen tetap menjalankan persekolahannya dengan ciri khas dalam semangat kerjasama negara dan Gereja.

Sekolah-sekolah swasta Kristen yang ada di Indonesiasaat ini, sebenarnya merupakan sekolah-sekolah Swasta Kristen warisan zending yang tergabung Schoolraad voor Christeljke Scholen in Netherlandsch Indie sejak tahun 1934 yang dikemudian hari, setelah Proklamasi Kemerdekaan, diganti menjadi Majelis Pusat Pendidikan Kristen (MPPK) (Soemanto \& Soeyarno, 1983:141; Sirait \& Tri, 2003:22)

\section{Penempatan Guru PNS yang diperbantukan pada Sekolah Swasta}

Kebijakan penempatan guru PNS yang diperbantukan pada sekolah swasta, menurut Suminto (1986:61), sebenarnya sudah berlangsung sejak pemerintahan kolonial Belanda menerapkan peraturan ordonansi sekolah liar yang mana pada pasal dua (2) menjabarkan bahwa: "sekolah swasta pribumi hanya bisa dididik/diajar oleh guru yang berasal dari lulusan pemerintah (Negara) ataupun dari sekolah swasta yang bersubsidi dari pemerintah (Negara)"
Di Indonesia, pemenuhan tenaga pendidik dan kependidikan,saat ini, diatur dalam Undang-Undang nomor 14 Tahun 2005 tentang Guru dan Dosen dimana Pasal 24 ayat 1, 2 dan 3 bermakna bahwa pemerintah baik Pusat, Provinsi maupun Kabupaten/Kota wajib memenuhi kebutuhan guru baik dalam jumlah, kualifikasi akademik maupun dalam kompetensi secara merata guna menjamin keberlangsungan satu satuan pendidikan; sedang pada ayat 4 mengatur keberadaan sekolah yang didirikan oleh masyarakat sebagai berikut:

"Penyelenggara pendidikan atau satuan pendidikan anak usia dini jalur pendidikan formal, pendidikan dasar, dan pendidikan menengah yang diselenggarakan oleh masyarakat wajib memenuhi kebutuhan gurutetap, baik dalam jumlah, kualifikasi akademik, maupun kompetensinya untuk menjamin keberlangsungan pendidikan"

Pernyataan tersebut menjelaskan bahwa baik pemerintah (Pusat, Provinsi dan Kabupaten/Kota) maupun masyarakat mempunyai peranan dalam hal pemenuhan Guru dalam menjamin keberlangsungan satu satuan pendidikan. Sedangkan, Peraturan Pemerintah (PP) nomor 74 tahun 2008 tentang Guru mengatur secara khusus mengenai pemenuhan guru baik dalam jumlah, kualifikasi akademik maupun dalam kompetensinya.

\section{Eksistensi Sekolah Swasta Kristen}

Negara bertanggung jawab dalam penyelenggaraan pendidikan bagi warga negaranya. Hak untuk memperoleh pendidikan mewajibkan negara untuk memfasilitasinya. Negara tidak boleh membedakan antara swasta dan negeri (Sirait \& Tri, 2003:78-79).

Di Belanda, eksistensi sekolah swasta Kristen didukung penuh oleh pemerintah dengan membiayai secara langsung tenaga guru swasta oleh negara, sedangkan negara menggunakan ujian negara sebagai kontrol 
mutu pendidikan (Karel \& Boudewijn, 1990 dalam Brummelen, 1993). Berbeda halnya di Prancis, eksistensi sekolah swasta Kristen akan didukung oleh pemerintah apabila sekolah swasta Kristen bersedia bersifat sekuler sehingga memunculkan sekolah swasta "quasi-state school” (sekolah semi negeri) dimana sekolah swasta Kristen - dominannya sekolah Katoliklebih memilih mempertahankan eksistensi sekolahnya walau tanpa bantuan pemerintah (Geoffrey, 1989:133; Frances, 1987 dalam Brummelen, 1993).

Di Swedia, PBB pernah mengecam praktik pendidikan dimana negara membedakan antara sekolah negeri dibandingkan dengan swasta dimana sekolah negeri diberi kemudahan dalam bentuk kebijakan dan fasilitasfasilitas pendidikan baik untuk siswa maupun guru negeri. Hal yang sama juga pernah dialami oleh Indonesia ketika negara berada pada masa pemerintahan Orde Baru (Sirait \& Tri, 2003:79).

Keberadaan sekolah swasta di Indonesia, telah ada sejak kolonialisme Belanda dan dikenal dengan nama "sekolah liar" dimana semakin meningkat ketika Belanda menghadapi kondisi krisis ekonomi pada tahun 1880. Lulusan dari "sekolah liar" tidak dapat diterima di kantor-kantor pemerintahan apabila tidak mampu memenuhi ordonansi sekolah liar yang mulai diberlakukan pada tanggal 1 Oktober 1932 yang mana di dalamnya berisi tiga aturan pokok yakni:

a. Sebelum memperoleh ijin tertulis dari pemerintah, suatu lembaga pendidikan yang tidak sepenuhnya dibiayai oleh dana pemerintah tidak dibenarkan memulai aktivitasnya;

b. hanya lulusan sekolah pemerintah atau sekolah swasta bersubsidi yang dinilai baik oleh pemerintah berhak mengajar di sekolah ini;

c. Ordonansi ini tidak berlaku bagi lembaga pendidikan agama (Suminto, 1986:58-61).
Pasca kemerdekaan Indonesia, realitas eksistensi sekolah swasta Kristen diwarnai oleh pengaruh dari faktor internal dan faktor eksternal. Faktor internal didominasi oleh kegagalan manajemen sekolah atau YPK dalam menjalankan fungsi maupun merespon perubahan yang ada serta kurangnya daya saing YPK baik dalam dana maupun strategi bertahan dalam menghadapi booming sekolah swasta maupun negeri yang bermunculan dengan segala fasilitas dan perlengkapannya (Kusyadi, 1989; Widihandojo, 2000 dalam Sulasmono, 2010; Slameto \& Wasitohadi, 2000:1).

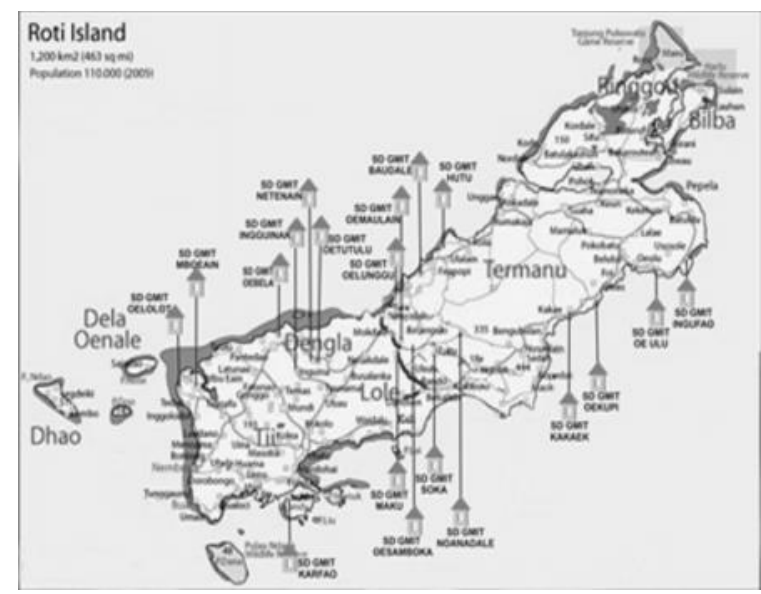

Sumber: www.indonesiatraveling.com(2013).

Data lokasi SD GMIT di Rote ditambahkan oleh penulis (2013)

Sedangkan, faktor eksternal disebabkan hubungan pemerintah/kekuasaan politik dengan sekolah swasta Kristen dari segi kebijakan pendidikan (Sulasmono, 2010:69). Sirait \& Tri (2003:79) menjelaskan faktor realitas faktor eksternal ini dimana seringnya pemerintah cenderung menggunakan sistem pendidikan sebagai alat untuk mendiskriminasikan ras, agama dan kelompok-kelompok minoritas serta kelompok-kelompok rentan lainnya.

\section{METODE}

Penelitian ini dilakukan pada delapan (8) SD GMIT di Kabupaten Rote Ndao. Delapan 
SD GMIT yang dimaksudkan adalah SD GMIT Netenain, Oetutulu, Oemaulain, Oesamboka, Maku, Soka, Naonadale, dan Oelunggu. Penelitian ini menggunakan metode penelitian kualitatif deskriptif dengan teknik pengumpulan data in-depth interview yang didukung dengan observasi, dokumentasi serta triangulasi.

\section{HASIL PENELITIANDAN PEMBAHASAN \\ Relasi antara negara dan GMIT pada SD GMIT di Rote Ndao}

Hasil penelitian menunjukkan bahwa antara Negara dan Gereja (GMIT) terdapat relasi dalam hal penempatan guru PNS yang diperbantukan pada pengelolaan SD GMIT yang ada di Rote Ndao. Relasi tersebut, saat ini, didominasi oleh negara, dimana secara mutlak, pada SD GMIT di Rote Ndao sudah tidak terdapat satupun guru Yayasan. (Laporan Data Inventaris SD GMIT Kabupaten Rote Ndao tahun 2013 dan wawancara dengan Mama Manno pada tanggal 27 Juni 2013). Penempatan guru PNS yang diperbantukan pada SD GMIT di Rote Ndao pun sudah tanpa pemberi-tahuan kepada pihak GMIT -melalui Yupenkris- (Wawancara dengan Benjamin Keo pada tanggal 18 Juni 2013). GMIT juga sudah tidak ambil peduli lagi mengenai perkembangan dan nasib guru PNS yang diperbantukan pada SD GMIT yang ada (Wawancara dengan Sarah Giri pada tanggal 27 Juni 2013).

Dominannya guru PNS yang diperbantukan pada SD GMIT di Rote Ndao dimulai ketika negara, pada masa pemerintahan Orde Baru, melakukan pengontrolan secara ketat persekolahan swasta serta lebih dianak emaskannya sekolah Negeri/Inpres sehingga menimbulkan kesan bahwa pendidikan hanyalah merupakan urusan negara saja sedangkan stakeholder dan elemen masyarakat gereja di dalam GMIT dipisahkan dari penyelenggaraan persekolahan SD GMIT (Wawancara dengan Yohanes Aplugi pada tanggal 27 Juni 2013).
Hal ini berdampak pada hilangnya semua guru jemaat-guru yang selain melayani persekolahan GMIT juga melayani di gereja, yang berlangsung hingga saat ini pada SD GMIT yang ada, padahal guru-guru inilah yang paling dominan ada pada SD GMIT di Rote Ndao (Wawancara dengan Yohanes Aplugi pada tanggal 27 Juni 2013).

Dominannya, secara mutlak, guru PNS yang diperbantukan, menyebabkan GMIT melalui Yupenkris cabang Rote Ndaokehilangan grip terhadap SD GMIT yang dimilikinya sedangkan GMIT sendiri tidak mempunyai kemandirian dana dalam mengelola SD GMIT yang dimilikinya disebab oleh minimnya partisipasi masyarakat GMIT dalam hal pembiayaan pendidikan (Wawancara dengan Yohanes Aplugi pada tanggal 27 Juni 2013).

Ketergantungan SD GMIT di Rote Ndao terhadap negara dalam operasional sekolah (baik dana pembiayaan pendidikan maupun pemenuhan sumber daya manusia/guru) menempatkan SD GMIT pada status yang oleh Geoffrey (1989:133) dalam Brummelen (1993) diistilahkan sebagai "quasi-state school" dimana hak kepemilikan sekolah tersebut adalah kepunyaan Yayasan/swasta tetapi semua operasional sekolah termasuk pemenuhan sumber daya manusia (SDM) bertumpu pada negara.

\section{Dampak penempatan guru PNS, secara deskriptif, terhadap eksistensi SD GMIT di Rote Ndao}

Dengan semakin kokohnya dominasi negara dalam penempatan guru PNS yang diperbantukan pada SD GMIT di Rote Ndao, yang didukung dengan subsidi dana pendidikan BOS dan DAK, berdampak pada loyalitas PNS yang diperbantukan pada SD GMIT dimana lebih cenderung condong mengarah kepada Negara dibandingkan kepada GMIT - melalui Yupenkris - sebagai Yayasan pengelolanya. 
Kecondongan ini terlihat dengan tidak adanya lagi laporan pertanggung jawaban dari SD-SD GMIT yang ada di Rote Ndao kepada pihak GMIT - baik kepada Sekretaris Umum Yupenkris di Kupang ataupun kepada Sekretaris Perwakilan Yupenkris cabang Rote Ndao-. Semua laporan pertanggung jawaban dikirim kepada Dinas Pendidikan, Pemuda dan Olahraga (PPO) baik di tingkat Kecamatan maupun tingkat Kabupaten (Wawancara dengan Sarah Giri pada tanggal 27 Juni 2013, Oktovianus Tanobes pada tanggal 29 juni 2013 dan Zakarias Manafe pada tanggal 4 Juli 2013).

Ketiadaan loyalitas PNS yang diperbantukan pada SD GMIT terhadap Yayasan pengelolaannya serta terputusnya hubungan antara GMIT -melalui Yupenkris- dengan SD GMIT yang dimilikinya tidak menyebabkan eksistensi SD GMIT di Rote Ndao, secara kuantitas, merosot. Justru, merosotnya SD GMIT di Rote Ndao, secara kuantitas, lebih disebabkan oleh kekuatan negara seperti pada kasus pe"negeri"an/peng "inpres"an pada era pemerintahan Orde Baru seperti yang dipaparkan berikut ini:

"Dulu sekolah-sekolah negeri itu hanya beberapa saja. Ini saya lihat pada yang ada di Rote Barat Laut saja. Beberapa saja. Tapi suatu waktu di situ sekitar tahun 1970an, kalau tidak salah tahun 1972 atau tahun 1973 itu yang kemudian terjadi perubahan status dari GMIT ke Negeri antara lain yaitu SD GMIT Oelua menjadi SD Negeri Oelua, SD GMIT Busalangga menjadi SD Inpres Busalangga dan juga SD GMIT Ndau menjadi SD Inpres Ndau. Semua SD dinegerikan pada tahun yang sama. Itu menimbulkan sedikit keresahan juga dari pihak Yupenkris waktu itu karena pemberitahuan secara resmi kepada pihak Yupenkris tidak ada. Pokoknya penegerian atau peng"inpres"an SD GMIT itu langsung saja. Maksud saya pemberitahuan secara resmi tertulis tidak ada, tetapi kalau ada pertemuan-pertemuan selalu dikatakan bahwa SD ini sudah dinegerikan atau di inpreskan. Sudah bukan GMIT lagi tapi sudah negeri (Wawancara dengan Yohanes Aplugi pada tanggal 27 Juni 2013).

Bargaining power Negara pada masa pemerintahan Orde Baru ini menyebabkan eksistensi SD GMIT di Rote Ndao, secara kuantitas, merosot tajam dari yang awalnya berjumlah 48 SD GMIT hanya menyisakan 19 SD GMIT yang tetap bertahan hingga saat ini (Frank, 1976: 57, 238).

Dominasi peranan dan bargaining power negara, saat ini, pada SD GMIT yang ada di Rote Ndao juga menempatkan SD GMIT sebagai kasta kedua di bawah SD Negeri dan SD Inpres. Hal ini terlihat dalam hal penilaian berkas kelayakan kenaikan pangkat bagi guru PNS yang hendak dievaluasi oleh Kepala Sekolah seperti yang dikutip berikut ini:

"Kalau usul kenaikan pangkat, guru pada SD GMIT Oemaulain harus "menginduk" dari SD Negeri atau SD Inpres. Jadi, bukan Kepala Sekolah di SD GMIT Oemaulain yang menilai kinerja gurunya melainkan Kepala Sekolah dari SD Negeri/Inpres yang harus menilai kinerja gurunya. Itupun kita yang harus mencarinya" (Wawancara dengan Oktovianus Tanobes pada tanggal 29 Juni 2013).

"Kalau semisalnya bukan Kepala Sekolah SD Negeri/Inpres yang menilai kelayakan kenaikan pangkat dari guru PNS yang diperbantukan pada SD GMIT di Rote Ndao maka berkasnya akan ditahan atau tertunda" (Wawancara dengan Sarah Giri pada tanggal 27 Juni 2013).

Situasi eksistensi SD GMIT di Rote Ndao dalam hal rekomendasi kenaikan pangkat sebagai kasta kedua, sudah terjadi secara menyeluruh pada seluruh SD GMIT yang ada di wilayah kerja GMIT -melalui Yupenkris(Focus Group Discussion pada tanggal 07 Juni 2013). Wilayah kerja GMIT -melalui Yupenkris- meliputi Delapan (8) Kabupaten dan satu (1) Kota yakni Kota Kupang, Kabupaten Kupang, TTS, TTU, Belu, Alor, Ende, Rote 
Ndao, dan Sabu Raijua (Laporan Majelis Yupenkris GMIT tahun 2012).

\section{KESIMPULAN}

Dari pembahasan hasil penelitian di atas, dapat ditarik kesimpulan sebagai berikut:

1. Negara dan GMIT dalam pengelolaan SD GMIT berlangsung dalam relasi satu arah yang didominasi oleh Negara sedangkan GMIT sudah tidak memiliki peran apapun dalam pengelolaan SD GMIT di Rote Ndao.

2. Status quasi-state school sampai saat ini masih melekat pada SD GMIT di Rote Ndao disebabkan karena ketidakmandirian Yayasan pengelola SD GMIT dan semakin dominannya peran negara.

3. Dominan tenaga pendidik/guru pada SD GMIT di Rote Ndao adalah guru PNS yang diperbantukan sedangkan guru Yayasan tidak ada sama sekali.

4. Dominannya guru PNS yang diperbantukan pada SD GMIT turut memberi dampak terhadap eksistensi SD GMIT di Rote Ndao dimana GMIT -melalui Yupenkris- sudah kehilangan grip terhadap SD GMIT yang dimilikinya disebabkan guru PNS yang diperbantukan lebih loyal kepada negara daripada kepada GMIT -melalui Yupenkris-

5. Peranan negara yang semakin kokoh dalam persekolahan SD GMIT di Rote Ndao menimbulkan bargaining power pemerintah yang berdampak pada eksistensi SD GMIT di Rote Ndao yang dianggap sebagai kasta kedua

\section{DAFTAR PUSTAKA}

Azra, Azyumardi. 2008. Pendidikan Islam di Era Globalisasi: Peluang dan Tantangan. Jurnal Penelitian Pendidikan Agama dan Keagamaan 6 (4): 123-137.

Cully, Iris. 2009. The Dinamics of Christian Education. Diterjemahkan oleh P. Siahaan dan Stephen Suleeman. Jakarta: PT. BPK Gunung Mulia.
Darmaningtyas. 2006. Pendidikan di NTT: Potret Tantangan dan Arah Solusinya. Majalah Lembaga Penelitian Smeru No. 20: Oktober-Desember Hal: 33-36.

Darmaputera, Eka. 1994. Aspek-Aspek EtisTeologis Hubungan Gereja-Negara dan Implikasi Dalam Negara Pancasila. Jakarta: PT BPK Gunung Mulia.

Direktorat Jenderal Bimbingan Masyarakat (Kristen) Protestan. 1982. Memahami Keberadaan Agama/Umat Kristen/Protestan di Tengah-tengah Tugas Pelayanan Pemerintah. Departemen Agama.

Frances., C. Fowler. 1987. The French Experience with Public Aidto Private Schools. Phi Delta Kappan, 68(5): 356-59 dalam Brummelen Harro van.1993. The Effects of Government Funding on Private Schools: Appraising the Perceptions of Longterm Principals and Teachers in British Columbia's Christian Schools. Canadian Journal of Education 18(1): 14-28.

Geoffrey, Walford. 1989. Private Schools in Ten Countries: Policy and Practice. Routledge: London and New York dalam Brummelen Harro van.1993. The Effects of Government Funding on Private Schools: Appraising the Perceptions of Longterm Principals and Teachers in British Columbia's Christian Schools. Canadian Journal of Education 18(1): 14-28.

Karel, Seashore Louis and Boudewijn A. M. van Velzen. 1991. A Look at Choice in the Netherlands. Educational Leadership 48(4): 67 dalam Brummelen Harro van.1993. The Effects of Government Funding on Private Schools: Appraising the Perceptions of Longterm Principals and Teachers in British Columbia's Christian Schools. Canadian Journal of Education 18(1): 14-28. 
Kurniawan, Bachtiar Dwi. 2011. Implementasi Kebijakan Sertifikasi Guru Dalam Rangka Meningkatkan Profesionalitas Guru di Kota Yogyakarta. Jurnal Studi Pemerintahan 2(2): 259-278.

Kusyadi.1989. Kemandirian Dana Untuk Menyelenggarakan Pendidikan Yang Bermutu Dalam Rangka Mempertahankan Eksistensi Sekolah-Sekolah Kristen. Majalah FKIP: Universitas Kristen Satya Wacana Tahun III No. 5, hlm: 24-30.

Laporan Majelis Pendidikan Yayasan Usaha Pendidikan Kristen (Yupenkris) Gereja Masehi Injili di Timor (GMIT) Tanggal 24-27 September 2012. Kupang.

Sirait, Jerry Rudolf \& Tri Atmo Yuwono. 2003. Sekarang, Bangkit dan Berdirilah: Proceeding Bulan Pendidikan Kristen di Indonesia Tahun 2003. Jakarta: BPK Gunung Mulia.

Slameto \& Wasitohadi. 2000. Manajemen BPSK dan Sekolah Kristen Dalam Satu Yayasan di Propinsi DIY. Jurusan Studi PPKn Fakultas Keguruan dan Ilmu Pendidikan Universitas Kristen Satya Wacana. Salatiga.

Sulasmono., Bambang S. 2010. Interaksi Negara dan Civil Society Dalam Kancah Pendidikan Agama di Daerah Istimewa Yogyakarta 1998-2003 (Laporan Penelitian). Salatiga: Widya Sari Press.
Suminto, H Aqib. 1986. Politik Islam Hindia Belanda: Het Kantoor voor Inlandsche zaken. Jakarta: Lembaga Penelitian Pendidikan dan Penerangan Ekonomi dan Sosial.

Supriadi, Djudjun Djaenudin. 2005. Tinjauan Kritis Penerapan Pendidikan Kristiani. Jurnal Pendidikan Penabur No.4 Tahun IV Hal: 43-52.

Supriyoko, Ki. 2011. dalam Kompas Online. 2011. Melukai Sekolah Swasta. http:// nasional. kompas.com/read/\%202011/02/ 22/03343398/Melukai. Sekolah.Swasta (Diakses pada tanggal 27 Februari 2013).

Soemanto, Wasty \& Soeyarno. 1983. Landasan Historis: Pendidikan Indonesia. Surabaya: Usaha Nasional.

Wolterbeek, J.D. 1995. Babad Zending di Pulau Jawa. Yogyakarta: Taman Pustaka Kristen dalam Sulasmono Bambang S. 2010. Interaksi Negara dan Civil Society Dalam Kancah Pendidikan Agama di Daerah Istimewa Yogyakarta 1998-2003 (Laporan Penelitian). Salatiga: Widya Sari Press. 